\title{
STUDY OF LIVER FUNCTION TEST IN CIRRHOTIC PATIENT
}

\author{
UDDIN MN ${ }^{1}$, JAHAN NWB ${ }^{2}$, SULTAN K ${ }^{3}$, NUSHRAT R ${ }^{4}$, ALI J ${ }^{5}$, KABIR HK ${ }^{5}$, BISWAS PK ${ }^{6}$, \\ BHUIYAN ME ${ }^{7}$, MURSHED KM ${ }^{8}$, SULTANA $\mathrm{S}^{9}$
}

\begin{abstract}
Aim: The study was carried out to see the Serum Bilirubin, ALT, AST and Alkaline Phosphatase as liver function in liver cirrhotic patient.

Method: The study was carried out among 50 well-compensated patients of cirrhosis of liver irrespective of their age, sex, residence \& income group. Patient was randomly selected while they were hospitalized in Dhaka Medical College Hospital, Sir Salimullah Medical College \& Mitford Hospital and Bangabandhu Sheikh Mujib Medical University.

Result: Serum Bilirubin, AST, ALT and Alkaline Phosphatase level were done in 50 (fifty) cirrhotic patient out of whom 38 were male and 12 were female. Mild to severe level of serum bilirubin were documented in $50 \%$ patients. Two-fold and fourfold rise of ALT were formed in $48 \%$ and $10 \%$ cirrhotic patient respectively. Similar pattern of rise of AST also shown in $50 \%$ cirrhotic patient. Alkaline Phosphatase value was normal in 92\% patient and of 08\% two-fold rise of Alkaline Phosphatase Alkaline Phosphatase.
\end{abstract}

Key words: ALT, AST, Alkaline Phosphatase, Cirrhosis.

J Dhaka Med Coll. 2019; 28(2) : 190-191

\section{Introduction}

Alanine amino transferase (ALT) a cytoplasmic enzyme and Aspartate aminotransferase (AST) present both in cytoplasm and mitochondria and the two important aminotransferases. Normal plasma contains low activities of both enzymes. Neither enzyme is specific to the liver, but ALT occur in much higher concentrate in liver than elsewhere and consequently increased serum ALT activity reflect hepatic damage more specifically.

ALT and AST are liberated into the blood whenever liver cells are damaged and increased plasma enzyme activity is a sensitivity index of hepatic damaged. Plasma ALT and AST activity test the integrity of liver cells and any acute liver damaged causes the highest activity. Patient with compensated cirrhosis generally show normal or only modest elevation of serum aminotransferase. ${ }^{1}$

Alkaline Phosphatase is situated in the canalicular and sinusoidal membranes of liver cells. Plasma Alkaline Phosphatase activity does not usually raise more than two-fold in acute chronic hepatocellular disease. Greatly increased plasma Alkaline Phosphatase activity is man biochemical indicator of biliary obstruction. ${ }^{2}$

\section{Methods and material}

The study was carried out among 50 wellcompensated patients of cirrhosis of liver irrespective of their age, sex, residence $\&$ income group. Patient was randomly selected while they were hospitalized in Dhaka Medical College Hospital, Sir Salimullah Medical College \& Mitford Hospital and Bangabandhu Sheikh Mujib Medical University. The patients were explained about the purpose.

1. Dr. Md. Nasir Uddin, Associate Professor, Department of Clinical Biochemistry, National Institute of Cardiovascular Diseases \& Hospital (NICVD), Dhaka

2. Dr. Nur-Wa-Bushra Jahan, Assistant Professor, Department of Obstetrics \& Gynaecology, Sir Salimullah Medical College \& Mitford Hospital, Dhaka

3. Dr. Kamal Sultan, Professor, Department of Biochemistry, Shaheed Suhrawardi Medical College, Dhaka

4. Dr. Rumana Nushrat, Professor, Department of Cardiology, National Institute of Cardiovascular Diseases \& Hospital (NICVD), Dhaka

5. Dr. Md. Julfiker Ali, Dr. Humayun Kabir, Associate Professor, Department of Cardiology, National Institute of Cardiovascular Diseases \& Hospital (NICVD), Dhaka

6. Dr. Prodip Kumar Biswas, Associate Professor, Department of Medicine, Dhaka Medical College, Dhaka

7. Dr. Md. Elias Bhuiyan, Assistant Professor of Medicine, Bangladesh Medical College

8. Dr. Khaled Mahbub Murshed, Department of Medcine, BSMMU, Dhaka

9. Dr. Shakera Sultana, Registrar, Department of Medicine, Dr. Sirajul Islam Medical College, Hospital, Dhaka Conferences: Dr. Md. Nasir Uddin, Associate Professor, Department of Clinical Biochemistry, National Institute of Cardiovascular Diseases \& Hospital (NICVD), Dhaka 


\section{Results}

Serum Bilirubin level, AST, ALT and Alkaline Phosphatase of Cirrhotic patient shown in table.

\begin{tabular}{|c|c|c|c|c|}
\hline \multirow[t]{2}{*}{ Parameter } & \multicolumn{4}{|c|}{ Case Subject } \\
\hline & Number & Percent & Mean & $\pm \mathrm{SD}$ \\
\hline \multicolumn{5}{|c|}{ Serum Bilirubin (mg/dl) } \\
\hline Normal $(<1.0)$ & 25 & 50 & & \\
\hline Mild $(1.1-6.0)$ & 23 & 46 & 2.05 & 2.98 \\
\hline Severe $(>12.1)$ & 02 & 04 & & \\
\hline \multicolumn{5}{|l|}{$\operatorname{SGPT}(\mu / 1)$} \\
\hline$<40$ & 21 & 42 & & \\
\hline $40-80$ & 24 & 48 & 52.89 & 26.72 \\
\hline $81-160$ & 05 & 10 & & \\
\hline \multicolumn{5}{|l|}{$\operatorname{SGOT}(\mu / 1)$} \\
\hline$<35$ & 25 & 50 & & \\
\hline $36-80$ & 21 & 42 & 51.61 & 37.35 \\
\hline$>81$ & 04 & 08 & & \\
\hline \multicolumn{5}{|c|}{ Alkaline phosphatase $(\mu / 1)$} \\
\hline $200-400$ & 46 & 92 & 183.18 & 134 \\
\hline$>400$ & 04 & 08 & & \\
\hline
\end{tabular}

Mild to severe level of serum bilirubin were documented in $50 \%$ of the patient. Two-fold $(41-80 \mu / 1)$ and four-fold rise of ALT (SGPT) were found in $48 \%$ and $10 \%$ cirrhotic patient. Similar pattern of rise of AST (SGOT) value was shown in $50 \%$ cirrhotic patient.

Alkaline Phosphatase value was normal in 92\% patient and only $08 \%$ patient has two-fold rise of alkaline phosphatase.

\section{Discussion}

In this study Serum bilirubin was normal in $50 \%$ patient but mild to severe in case of other $50 \%$ patient. This is $50 \%$ like reported by others. ${ }^{1}$ this is due to fact that cirrhosis causes liver cell injury and may cause defective execution in bilirubin. ${ }^{3}$

Serum AST and ALT level were increase in cirrhotic patient by two-fold to four-fold. This is like report by others. ${ }^{4,5}$ They suggest that in cirrhosis, liver cell injury causes release of enzyme AST and ALT, those present in the cell.

Serum Alkaline phosphates level was normal in $92 \%$ patient; only $08 \%$ patient has increase alkaline phosphatase level. This is consisted with others. ${ }^{6,7}$ They reported that alcoholisms main cause of cirrhosis, which does not change Alkaline phosphatase level remarkably. Only Biliary cirrhosis and obstructive jaundice causes marked increase of alkaline phosphatase level.

\section{Conclusion}

The prevalence of liver cirrhosis is increasing day by day in the society. Serum bilirubin, ALT, AST and Alkaline Phosphatase is the important parameter of liver function and it can be used as diagnostic and prognostic tool of liver cirrhosis. So, this study may help to diagnose the disease a little bit but can help to manage the disease and prognosis of the disease.

\section{References}

1. Edwards RW and Boucher AD (1999). Davidson's Principles and Practice of Medicine. $18^{\text {th }}$ edn. Churchill Livingstone, UK, pp 525-528, pp695-709

2. Dooley SS (1993). Disease of Liver and Biliary system, 7th edition, Black Well Scientific publication. Oxford.

3. Thomson AD (1981). Cirrhosis of liver, the peact: 225:449-459

4. Anthony PP, Vogel CL, Sadikhali Fetal (1972) Hepatitis associated Antigen and antibody in Uganda. Correlation of sociological testing with Histopathology, Br.Med.J: 403-406

5. Kumer PJ and Clarke M (1994). Clinical Medicine. A Textbook for Medical Students and Doctors, $3^{\text {rd }}$ edition, published by ELBS, London.P.260-273

6. Islam MN and Zaman APMS (1978). Clinical presentation of cirrhosis of liver, BMJ. 16(4), 85

7. Conn HO (11976). Scihiffs disease of the liver, $4^{\text {th }}$ edition, Philadelphia.JB.Lippincort Company, P833. 